\title{
Structural chromosome aberrations cause swelling of the nucleus
}

Kenji Takeshita ${ }^{1,2^{*}}$, Hiroaki I. Ogawa ${ }^{1}$ and Toshinari Maeda ${ }^{1}$

\begin{abstract}
Background: Carcinogens are known to cause swelling of the mammalian cell nucleus. However, the mechanism of the swelling and its toxicological significance have not been fully elucidated. Since nuclear swelling (NS hereafter) has been frequently observed in chromosomal aberration (CA hereafter) tests (in vitro), the relationship between NS and CAs was investigated in this study.

Results: In a short-term CA test using the fibroblast CHL cell line, the appearance of NS increased in a dose-dependent manner after exposure to six types of clastogens (mitomycin C, methyl methane sulfonate, 1-methyl-3-nitro-1-nitrosoguanidine, benzo[a]pyrene, cyclophosphamide monohydrate, and 9,10-dimethyl-2-benzanthracene), and a strong correlation was found between NS (\%) and CAs (\%) at each dosage. Therefore, we hypothesized that clastogens cause NS in cultured mammalian cells, since the mouse lymphoma L5178Y cell line is known to have a similar sensitivity to clastogens. Thus, we measured NS for 14 compounds (clastogens) that are known to induce structural CAs, 4 aneugens, and 12 non-mutagenes. Almost all clastogens caused NS of more than $5 \%$, which increased in a dose-dependent manner. Among the aneugens, colchicine, and diethylstilbestrol caused the same level of NS \% as the clastogens, while carbendazim and trichlorfon caused a similar level of NS \% as the clastogens only at higher levels of cytotoxicity. Almost all the non-mutagens caused less than $5 \%$ NS.
\end{abstract}

Conclusions: These results strongly suggest that NS is mainly caused by structural aberrations in the nucleus during interphase of the cell cycle.

Keywords: Chromosomal aberration, Nuclear swelling, Clastogen, Genotoxicity, Aneugen, Carcinogen, Non-mutagen

\section{Background}

Carcinogens cause swelling of the mammalian cell nucleus, a phenomenon first reported by Page [1]. Numerous studies have evaluated nuclear swelling (NS), including in cultured mammalian cells (e.g., HeLa S3 cells) by Agrelo [2]. Grant and Finch et al. proposed a screening test (nuclear enlargement assay) for identifying carcinogens based on NS [3, 4]. However, as described by Westmoreland et al., because most instances of NS are independent of abnormal enhancement of DNA synthesis [5], the mechanism of NS differs from those occurring in cellular senescence and

\footnotetext{
* Correspondence: kenji.takeshita@ube-ind.co.jp

${ }^{1}$ Department of Biological Functions Engineering, Graduate School of Life Science and Systems Engineering, Kyushu Institute of Technology, 2-4 Hibikino, Wakamatsu-ku, Fukuoka 808-0196, Japan

${ }^{2}$ UBE Scientific Analysis Laboratory, Inc, 1978-5 Kogushi, Ube, Yamaguchi 755-8633, Japan
}

(c) 2016 The Author(s). Open Access This article is distributed under the terms of the Creative Commons Attribution 4.0 International License (http://creativecommons.org/licenses/by/4.0/), which permits unrestricted use, distribution, and reproduction in any medium, provided you give appropriate credit to the original author(s) and the source, provide a link to the Creative Commons license, and indicate if changes were made. The Creative Commons Public Domain Dedication waiver (http://creativecommons.org/publicdomain/zero/1.0/) applies to the data made available in this article, unless otherwise stated.

cancerous cells [6, 7]. The mechanisms of NS and its toxicological significance remain unclear. Most carcinogens that cause NS are genotoxins, which cause DNA damage, chromosomal aberrations (CAs), and micronucleus formation. Because NS is often observed during the mammalian CA test (in vitro), we examined the relationship between NS and CAs. If NS is related to genotoxicity, it may be useful to measure NS in various cultured mammalian cell lines; we obtained additional information nearly simultaneously through additional microgram-scale sampling during the respective cell assays.

In this study, the correlation between NS and CAs was examined using $\mathrm{CA}$ tests for clastogens in the Chinese hamster lung $\mathrm{CHL} / \mathrm{IU}$ cell line. NS measurements were carried out using compounds known to induce structural CAs in the mouse lymphoma L5178Y cell line. L5178Y is often used in mouse lymphoma L5178Y cell Tk (thymidine 
kinase) gene mutation assays. These assays can detect mutations in the Tk gene that result from both gene mutations and chromosome damage. It has also been reported that MMS, MNNG, 2AF, B (a) P, and DMBA cause chromosomal aberrations in L5178Y [8-11], and thus we hypothesized that L5178Y has a similar sensitivity to clastogens as the CHL $[12,13]$.

\section{Methods}

Cells

The CHL cell line was obtained from the Health Science Research Resources Bank (HSRRB, Osaka, Japan). The CHL cells were cultured in Eagle's MEM supplemented with $10 \%$ (v/v) heat-inactivated calf serum. Mouse lymphoma L5178Y $\mathrm{TK}^{+/}$3.7.2c cells (L5178Y hereafter) were donated by the National Institute of Health Sciences (Tokyo, Japan). The L5178Y cells were cultured in RPMI1640 supplemented with $10 \%(\mathrm{v} / \mathrm{v})$ heat-inactivated horse serum and sodium pyruvate $(200 \mu \mathrm{g} / \mathrm{ml})$ in a humidified incubator at $37{ }^{\circ} \mathrm{C}$ with $5 \% \mathrm{CO}_{2}$.

\section{Chemicals}

The chemicals used were chosen according to previous studies [14-21]. The tested compounds included 14 clastogens, 4 aneugens, and 12 non-mutagens (Table 1). These compounds were dissolved in dimethyl sulfoxide (DMSO) or physiological saline. The final concentration of the solvent to the culture medium was adjusted to $1 \%(\mathrm{v} / \mathrm{v})$ for each compound. The highest concentration for each compound was selected based on the minimum concentration that resulted in cytotoxicity. However, when a test compound showed no cytotoxicity, it was fixed to $500 \mu \mathrm{g} / \mathrm{ml}$ for clastogens and aneugens and to $2000 \mu \mathrm{g} / \mathrm{ml}$ for nonmutagens. The concentrations selected for analysis were in ratios of 2 or 4 to cover a wide concentration range (except for the ratio of $\sqrt{ } 2$ for cyclophosphamide).

\section{Metabolic activation system}

To determine the influence of metabolic activation for a test compound, S9 mix was used. The S9 fraction was prepared from male Sprague-Dawley rats that were pretreated with the enzyme-inducing agents phenobarbital and 5, 6-benzoflabone, which were obtained from the Oriental Yeast Co. Ltd (Tokyo, Japan). In the experiment, S9 mix was added so that the S9 fraction concentrations were $5 \%(\mathrm{v} / \mathrm{v})$ for $\mathrm{CHL}$ and $2 \%(\mathrm{v} / \mathrm{v})$ for L5178Y cells in the final test medium. The S9 mix for CHL cells was prepared as follows: $2 \mathrm{ml}$ of $\mathrm{S} 9$, $1.34 \mathrm{ml}$ of $20 \mathrm{mM}$ HEPES, $0.67 \mathrm{ml}$ of $50 \mathrm{mM} \mathrm{MgCl}_{2}$, $0.67 \mathrm{ml}$ of $330 \mathrm{mM} \mathrm{KCl}, 0.67 \mathrm{ml}$ of $50 \mathrm{mM}$ glucose-6phosphate, $0.67 \mathrm{mM}$ of $40 \mathrm{mM} \mathrm{NADP}\left(\mathrm{Na}_{2}\right)$, and $0.67 \mathrm{ml}$ of purified water. The S9 mix for L5178Y cells was prepared as follows: $2 \mathrm{ml}$ of $\mathrm{S} 9,1 \mathrm{ml}$ of $0.18 \mathrm{~g} / \mathrm{ml}$ glucose-6-phosphate, $1 \mathrm{ml}$ of $25 \mathrm{mg} / \mathrm{ml} \mathrm{NADP}$, and $1 \mathrm{ml}$ of $150 \mathrm{ml} \mathrm{KCl}$.

\section{Treatment for CHL cells}

Five milliliters of culture medium (4000 cells $/ \mathrm{ml}$ ) was added to a plastic Petri dish (60-mm diameter). After a 3-day incubation, the cells were exposed to the test compounds for $6 \mathrm{~h}$. When appropriate, S9 mix (for metabolic activation) was also added to the medium. Furthermore, an 18-h recovery time was needed, and $2 \mathrm{~h}$ before cell sample collection, colcemid was added to the medium at a final concentration of $0.2 \mu \mathrm{g} / \mathrm{ml}$ in order to harvest the cells in the metaphase state. Trypsin was used to separate the cells from the Petri dishes, and the obtained cells were used to measure or estimate NS and CAs.

\section{Treatment for L5178Y cells}

Cells $\left(400 \mu \mathrm{l}\right.$ at a density of $5 \times 10^{5}$ cells $\left./ \mathrm{ml}\right)$ in the exponential cell growth phase were cultured in $1.5 \mathrm{ml}$ micro-tubes, and the prescribed amounts of the test compounds were added, followed by the proper amount of $150 \mathrm{mM} \mathrm{KCl}$ (without metabolic activation) or S9 mix (with metabolic activation). After shaking gently at $37{ }^{\circ} \mathrm{C}$ in an incubator for $3 \mathrm{~h}$, the cells were collected using centrifugation, and the supernatant was removed. One milliliter of fresh medium was added to the microtube, and the mixture was transferred to a 24-well plate. After a 21-h incubation, NS was measured and analyzed.

\section{Analyses of CAs}

Cells were suspended and incubated in a $0.075 \mathrm{M} \mathrm{KCl}$ hypotonic solution for $15 \mathrm{~min}$ at $37{ }^{\circ} \mathrm{C}$, and they were then fixed in ice-cold Carnoy solution (1:3 = acetic acid: ethanol). The fixed cell suspension was dropped on a glass slide, air-dried, and stained with Giemsa solution. A total of 100 cell images in metaphase were observed per dose with a microscope (Olympus BX50) at 600x magnification. When the number of metaphase cells was less than 100 because of cytotoxicity, all metaphase cells were counted per dose.

\section{Measurements of NS}

Cell suspensions were fixed by adding formalin to a final concentration of $2 \%(\mathrm{v} / \mathrm{v})$, and the suspensions were then fluorescent stained by adding $50 \mu \mathrm{g} / \mathrm{ml}$ DAPI or $50 \mu \mathrm{g} / \mathrm{ml}$ Hoechst 33342 at a final concentration of 1 to $2 \%(\mathrm{v} / \mathrm{v})$ of the suspension. For CHL cells, the cell density was concentrated to 2 to 4 times, and the concentrated cell suspensions were placed between two glass plates with a 0.07-mm space using Sekisui microscopy plates (UR-137S) obtained from Sekisui Chemical Co., Ltd. A total of 72 pictures (frames) of the cells per dose were taken with a fluorescence microscope (Olympus BX50FLA equipped 
Table 1 List of compounds tested

\begin{tabular}{|c|c|c|c|c|}
\hline No. & Compound (Another name) & CAS No & Source & Solvent used \\
\hline & Clastogens & & & \\
\hline 1 & Mitomycine C (MMC) & $50-07-7$ & Wako & Saline \\
\hline 2 & Methyl methane sulfonate (MMS) & $66-27-3$ & Sigma-Aldrich & Saline \\
\hline 3 & 1-Methyl-3-nitro-1-nitrosoguanidine (MNNG) & $70-25-7$ & Wako & DMSO \\
\hline 4 & Benzo[a]pyrene (B[a]P) & $50-32-8$ & Wako & DMSO \\
\hline 5 & Cyclophosphamide Monohydrate (CP) & $6055-19-2$ & Wako & Saline \\
\hline 6 & 9,10-Dimethyl-1,2-benzanthracene (DMBA) & $57-97-6$ & Wako & DMSO \\
\hline 7 & Acetaminophen & $103-90-2$ & Wako & DMSO \\
\hline 8 & Sodium Azide & $26628-22-8$ & $\mathrm{Naca}$ & Saline \\
\hline 9 & 2-(2-Furyl)-3-(5-nitro-2-furyl)-acrylamide (AF2) & $3688-53-7$ & Wako & DMSO \\
\hline 10 & 4-Nitroquinoline 1-Oxide (4NQO) & $56-57-5$ & Wako & DMSO \\
\hline 11 & 2-Acetamidofluorene & $53-96-3$ & Wako & DMSO \\
\hline 12 & $\begin{array}{l}\text { 1-Methyl-5H-pyrido[4,3-b]indole-3-amine acetic } \\
\text { acid (Trp-P-2 Acetate) 1-Methyl-5H-pyrido } \\
\text { [4,3-b]indole-3-amine acetic acid (Trp-P-2 Acetate) }\end{array}$ & $72254-58-1$ & Wako & DMSO \\
\hline 13 & 2-Aminoanthracene & $613-13-8$ & Naca & DMSO \\
\hline \multirow[t]{2}{*}{14} & Diphenylamine & $122-39-4$ & Wako & DMSO \\
\hline & Aneugens & & & \\
\hline 15 & Methyl 2-benzimidazole carbamate (Carbendazim) & $10605-21-7$ & Wako & DMSO \\
\hline 16 & Colchicine & 64-86-8 & Wako & DMSO \\
\hline 17 & Diethylstilbestrol (DES) & $56-53-1$ & Wako & DMSO \\
\hline \multirow[t]{2}{*}{18} & $\begin{array}{l}\text { 2,2,2-Trichloro-1-hydroxyethyl } \\
\text { dimethyl phosphate (Trichlorfon) }\end{array}$ & $52-68-6$ & Wako & DMSO \\
\hline & Non-mutagens & & & \\
\hline 19 & Toluene & $108-88-3$ & Wako & DMSO \\
\hline 20 & o-Chlorotoluene & $95-49-8$ & Wako & DMSO \\
\hline 21 & Salicylic acid & $69-72-7$ & Wako & DMSO \\
\hline 22 & DL-Tartaric acid & $133-37-9$ & Wako & Saline \\
\hline 23 & 2,4,6-Trichloroaniline & $634-93-5$ & Wako & DMSO \\
\hline 24 & Diethyl phthalate & $84-66-2$ & Wako & DMSO \\
\hline 25 & L(+)-Ascorbic acid (Vitamin C) & $50-81-7$ & Wako & Saline \\
\hline 26 & $\beta$-Carotene & $7235-40-7$ & $\mathrm{TCl}$ & DMSO \\
\hline 27 & Methacrylamide & 79-39-0 & Wako & Saline \\
\hline 28 & Cyclohexene & $110-83-8$ & Wako & DMSO \\
\hline 29 & Isopropylamine & $75-31-0$ & Wako & Saline \\
\hline 30 & dl-a-Tocopherol (Vitamin E) & $10191-41-0$ & Wako & DMSO \\
\hline
\end{tabular}

Wako: Wako Pure Chemical Industries, Ltd

Naca: NACALAI TESQUE, INC

TCI: Tokyo Chemical Industry CO., LTD

with a 20x objective lens and a Nippon Roper chromosome inspection supporting system CIS-02) at a frame size of $646 \mu \mathrm{m} \times 483 \mu \mathrm{m}$. This was equivalent to taking pictures of $1.57 \mu \mathrm{l}$ of the cell suspension. The resulting image data were analyzed using Image-Pro Plus image analysis software (ver. 5), and the number of cell nuclei was counted, and their area was measured. Using standard measures of nuclear size, NS was discriminated from other conditions.

\section{Cytotoxicity assessment}

The following formula for cytotoxicity assessment was used:

Relative Increase in Cell Counts (RICC) [22-24] 
RICC $=\frac{(\text { Increase in number of cells in treated cultures }(\text { final }- \text { starting }))}{(\text { Increase in number of cells in control cultures (final-starting }))} \times 100$

\section{Statistical analysis}

Fisher's exact tests and Chi-squared tests were used to determine whether there were statistical differences between the negative control group and the treated group in the appearance of NS. For clastogen tests using CHL cells, the correlation coefficient $\left(\mathrm{r}^{2}\right)$ was calculated to evaluate the correlation between NS (\%) and CA (\%) at each concentration. The significance level was set at $p<0.05$ for all statistical analyses.

\section{Results}

\section{Nuclear size}

As shown in Fig. 1, since the maximum value of the standard deviation (SD) was approximately $5 \%$ for the frequency distribution of the cell nucleus area in the negative control group, a relative frequency (average $+\mathrm{SD}$ ) of more than $5 \%$ is indicated. The classifications of nuclear size (the mean value of respective classification) for the controls (without the test compounds) were as follows. For CHL cells, most nuclear sizes were approximately 60 to $150 \mu \mathrm{m}^{2}$, and for L5178Y cells, most nuclear sizes were approximately 50 to $100 \mu \mathrm{m}^{2}$. Hence, NS (\%) was defined as follows: cells with a nuclear size of more than $160 \mu^{2}$ for the CHL cell system and with a nuclear size of more than $110 \mu \mathrm{m}^{2}$ for the L5178Y cell system were classified as (or exhibiting) NS (\%).

\section{CAs and NS for CHL cells}

NS appeared mainly in the range $160-180 \mu \mathrm{m}^{2}$; the sum of the relative frequencies (average $+\mathrm{SD}$ ) of three classes for the negative controls was less than $5 \%$, and values greater than $5 \%$ were selected to be significant (Fig. 2). Assuming that the nucleus is a sphere, the nuclear volume is proportional to the square root of the cell cross-sectional area raised to the third power; this volume ratio for cell nuclei with NS (\%) was 1.1- to 1.3fold higher than that for the cell nuclei of the negative controls. The occurrence of NS compared to the negative controls occurred in a dose-dependent manner, and NS (\%) was strongly correlated with CAs (\%) caused by different clastogens (Table 2). However, in detail, MMS $(6.3 \mu \mathrm{g} / \mathrm{ml}$ and $13 \mu \mathrm{g} / \mathrm{ml})$ and MMNG $(0.31 \mu \mathrm{g} / \mathrm{ml})$ did not cause NS, although both clastogens caused CAs. On the contrary, DMBA $(2.0 \mu \mathrm{g} / \mathrm{ml})$ did not cause CAs but caused NS. Regardless, there were strong correlations in this system. For example, the minimum $\mathrm{r}^{2}$ of MNNG in this study was 0.84, while MMC and CP had higher $\mathrm{r}^{2}$ values of greater than 0.90 .
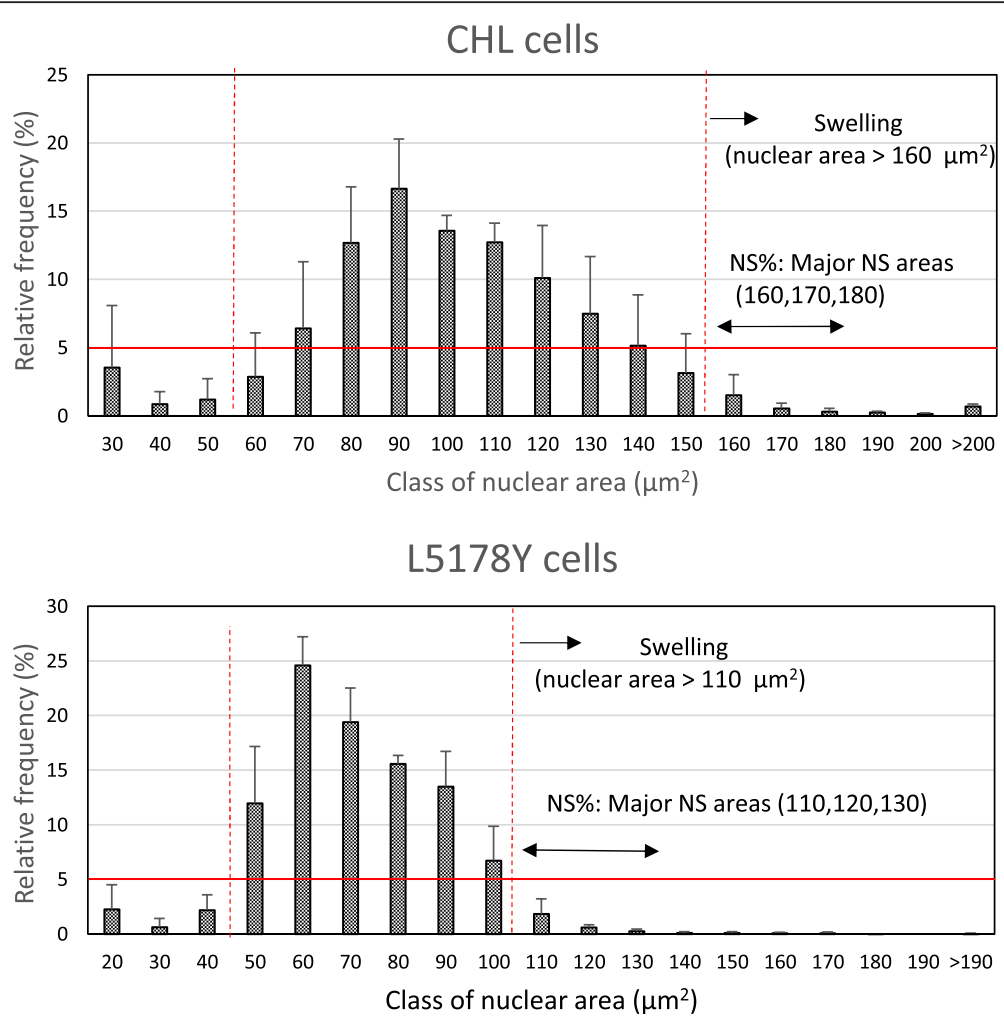

Fig. 1 Histogram of cell nuclear areas for the negative controls. The ordinates (relative frequency) are expressed as the mean \pm standard deviation (SD) values of six experiments. The error bars indicate the SD 


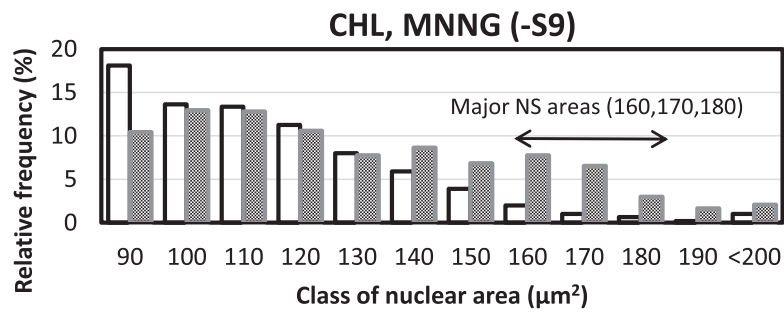

Negative control

$1.3 \mu \mathrm{g} / \mathrm{ml}$

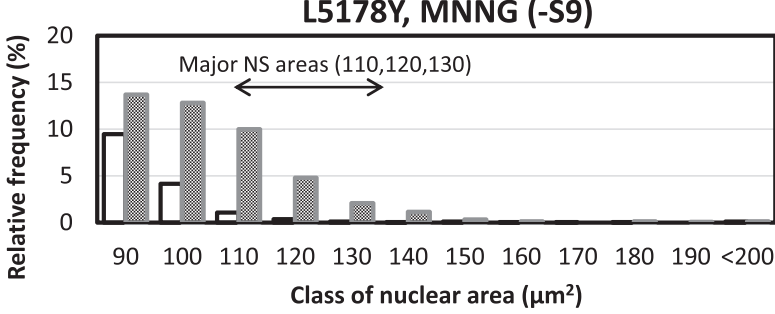

Negative control $0.49 \mu \mathrm{g} / \mathrm{ml}$

Fig. 2 Major nuclear swelling areas for CHL and L5178Y cells. Histogram of cell nuclear areas for clastogens (e.g., MNNG)

\section{NS of L5178Y cells}

For L5178Y cells, NS appeared in the nuclear size range of $110-130 \mu \mathrm{m}^{2}$ (Fig. 2), and most of the clastogens caused NS in a dose-dependent manner. However, MNNG and 2acetamidofluorene showed different behaviors, i.e., NS (\%) first increased and then decreased after reaching its maximum value, following a bell-shaped curve (Fig. 3). The NS values following aneugen exposure were less than those following clastogen exposure. However, NS (\%) values following colchicine and diethylstilbestrol (DES) exposure with metabolic activation were similar to those following clastogen exposures. Moreover, NS (\%) was significantly higher at high cytotoxicity levels (Fig. 4). For the nonmutagen test compounds, NS (\%) appeared at high cytotoxicity levels, and the values were statistically significant (Fig. 5). Diphenylamine with metabolic activation caused NS at a concentration of $2.0 \mu \mathrm{g} / \mathrm{ml}$ with a frequency of more than $5 \%$. The relation between RICC (\%) and NS (\%) indicates that the clastogen more strongly induces NS (\%) than the aneugens and non-mutagens (Fig. 6).

Table 2 Clastogens induced chromosome aberrations and nuclear swelling in CHL cells

\begin{tabular}{|c|c|c|c|c|c|c|c|c|c|c|c|c|c|c|c|c|}
\hline \multirow{3}{*}{ Compound } & \multirow{3}{*}{$\begin{array}{c}\text { Concentration } \\
(\mu \mathrm{g} / \mathrm{ml})\end{array}$} & \multirow{3}{*}{ S9 mix } & \multirow{3}{*}{$\begin{array}{l}\text { RICC } \\
(\%)\end{array}$} & \multicolumn{7}{|c|}{ Chromosome aberrations } & \multirow{3}{*}{$\begin{array}{c}\text { Observed } \\
\text { Cells }\end{array}$} & \multicolumn{4}{|c|}{ Nuclear swelling (\%) } & \multirow{3}{*}{$\begin{array}{l}\text { Correlation between } \\
\text { chromosome aberrations } \\
\text { and nuclear swellings }\end{array}$} \\
\hline & & & & \multicolumn{7}{|c|}{ No. of cells with structural aberrations } & & \multicolumn{4}{|c|}{ Class of nuclear area $\left(\mu \mathrm{m}^{2}\right)$} & \\
\hline & & & & Observed & $\mathrm{ctb}$ & cte & $\mathrm{csb}$ & cse & other & total $(\%)$ & & 160 & 170 & 180 & total & \\
\hline \multirow[t]{5}{*}{ MMC } & 0 & - & 100 & 100 & 1 & 0 & 0 & 1 & 0 & 2 & 940 & 0.3 & 0.3 & 0.5 & 1.2 & $\mathrm{r}^{2}=0.9595$ \\
\hline & 0.0076 & - & 81 & 100 & 1 & 4 & 0 & 0 & 0 & 5 & 770 & 0.8 & 0.3 & 0.1 & 1.2 & $p=0.0035$ \\
\hline & 0.031 & - & 75 & 100 & 2 & 8 & 0 & 0 & 0 & $9 *$ & 717 & $1.4^{*}$ & 0.6 & 0.1 & 2.1 & \\
\hline & 0.12 & - & 54 & 100 & 10 & 78 & 1 & 0 & 0 & $82 *$ & 526 & $7.0 *$ & $6.1 *$ & $3.8 *$ & $16.9 *$ & \\
\hline & 0.49 & - & 44 & 100 & 25 & 77 & 2 & 0 & 4 & $87 *$ & 438 & $10.0 *$ & $8.7 *$ & $5.5 *$ & $24.2 *$ & \\
\hline \multirow[t]{5}{*}{ MMS } & 0 & - & 100 & 100 & 0 & 0 & 0 & 0 & 0 & 0 & 735 & 1.0 & 0.5 & 0.0 & 1.5 & $\mathrm{r}^{2}=0.8913$ \\
\hline & 6.3 & - & 110 & 100 & 14 & 6 & 0 & 0 & 0 & $19 *$ & 997 & 1.1 & 0.6 & 0.3 & 2.0 & $p=0.0157$ \\
\hline & 13 & - & 104 & 100 & 24 & 14 & 0 & 0 & 0 & $36 *$ & 942 & 1.5 & 0.8 & 0.4 & 2.8 & \\
\hline & 25 & - & 108 & 100 & 30 & 47 & 0 & 0 & 0 & $65 *$ & 974 & $3.6 *$ & $2.4 *$ & 0.9 * & $6.9 *$ & \\
\hline & 50 & - & 72 & 100 & 6 & 97 & 0 & 0 & 0 & $100 *$ & 676 & $8.3 *$ & $4.7 *$ & $3.0 *$ & $16.0 *$ & \\
\hline \multirow[t]{5}{*}{ MNNG } & 0 & - & 100 & 100 & 1 & 2 & 0 & 0 & 0 & 3 & 1100 & 2.0 & 1.0 & 0.6 & 3.6 & $r^{2}=0.8396$ \\
\hline & 0.31 & - & 85 & 100 & 19 & 28 & 3 & 0 & 0 & $45 *$ & 782 & 2.3 & 1.8 & 0.1 & 4.2 & $p=0.0287$ \\
\hline & 0.63 & - & 67 & 100 & 36 & 48 & 2 & 0 & 0 & $64 *$ & 632 & $5.2 *$ & $2.5 *$ & 1.3 & $9.0 *$ & \\
\hline & 1.3 & - & 72 & 100 & 32 & 83 & 0 & 0 & 0 & $93 *$ & 671 & $7.7 *$ & $6.6 *$ & $3.0 *$ & $17.3 *$ & \\
\hline & 2.5 & - & 65 & 100 & 17 & 96 & 0 & 0 & 0 & $100 *$ & 617 & $6.0 *$ & $5.3 *$ & $4.1 *$ & $15.4 *$ & \\
\hline \multirow[t]{5}{*}{$\mathrm{B}[\mathrm{a}] \mathrm{P}$} & 0 & + & 100 & 100 & 0 & 0 & 0 & 0 & 0 & 0 & 770 & 0.3 & 0.0 & 0.1 & 0.4 & $\mathrm{r}^{2}=0.8507$ \\
\hline & 2.0 & + & 109 & 100 & 0 & 0 & 0 & 0 & 0 & 0 & 838 & 0.4 & 0.0 & 0.1 & 0.5 & $p=0.0257$ \\
\hline & 7.8 & + & 67 & 100 & 0 & 9 & 0 & 0 & 0 & $9^{*}$ & 531 & 1.1 & 0.4 & 0.8 & $2.3 *$ & \\
\hline & 31 & + & 54 & 100 & 9 & 42 & 0 & 0 & 2 & $46 *$ & 435 & $3.4 *$ & $1.6 *$ & 0.9 & $6.0 *$ & \\
\hline & 125 & + & 60 & 100 & 24 & 58 & 3 & 0 & 9 & $73 *$ & 478 & $8.6 *$ & $7.3 *$ & $8.2 *$ & $24.1 *$ & \\
\hline \multirow[t]{4}{*}{$\mathrm{CP}$} & 0 & + & 100 & 100 & 1 & 0 & 0 & 0 & 0 & 1 & 943 & 4.2 & 1.0 & 0.3 & 5.5 & $r^{2}=0.9270$ \\
\hline & 6.3 & + & 93 & 100 & 27 & 63 & 0 & 0 & 0 & $70^{*}$ & 883 & $8.3 *$ & $4.0^{*}$ & $2.7 *$ & $14.9 *$ & $p=0.0372$ \\
\hline & 8.8 & + & 93 & 100 & 1 & 93 & 0 & 0 & 0 & $94 *$ & 883 & $11.9 *$ & $7.5 *$ & $6.2 *$ & $25.6 *$ & \\
\hline & 13 & + & 90 & 100 & 0 & 100 & 0 & 0 & 0 & $100 *$ & 854 & $12.2 *$ & $6.4 *$ & $5.2 *$ & $23.8 *$ & \\
\hline \multirow[t]{5}{*}{ DMBA } & 0 & + & 100 & 100 & 0 & 0 & 0 & 0 & 0 & 0 & 3214 & 1.4 & 0.6 & 0.3 & 2.3 & $r^{2}=0.8814$ \\
\hline & 0.98 & + & 104 & 100 & 0 & 0 & 0 & 0 & 0 & 0 & 3352 & 1.7 & 0.8 & 0.1 & 2.7 & $p=0.0180$ \\
\hline & 2.0 & + & 116 & 100 & 0 & 1 & 0 & 0 & 0 & 1 & 3728 & $4.4 *$ & $2.3 *$ & $1.2 *$ & $7.8 *$ & \\
\hline & 3.9 & + & 71 & 100 & 6 & 9 & 0 & 0 & 0 & $13 *$ & 2308 & $4.7 *$ & $3.2 *$ & $1.3 *$ & $9.2 *$ & \\
\hline & 7.8 & + & 55 & 22 & 1 & 21 & 0 & 0 & 0 & $100 *$ & 1814 & $7.9 *$ & $7.4 *$ & $4.8 *$ & $20.1 *$ & \\
\hline
\end{tabular}

RICC relative increase in cell counts

ctb: chromatid break, cte: chromatid exchange, csb: chromosome break, cse: chromosome exchange, others: fragmentation etc class 160: $>150$ up to $160 \mu \mathrm{m}^{2}$, class $170:>160$ up to $170 \mu \mathrm{m}^{2}$, class $180:>170$ up to $180 \mu \mathrm{m}^{2}$

${ }^{*}$ Asterisks indicate statistically higher than controls ( ${ }^{*} p<0.05$; Fisher's exact test or Chi-squared test), White letters indicate clearly higher than controls (NS $>5 \%$ ) 


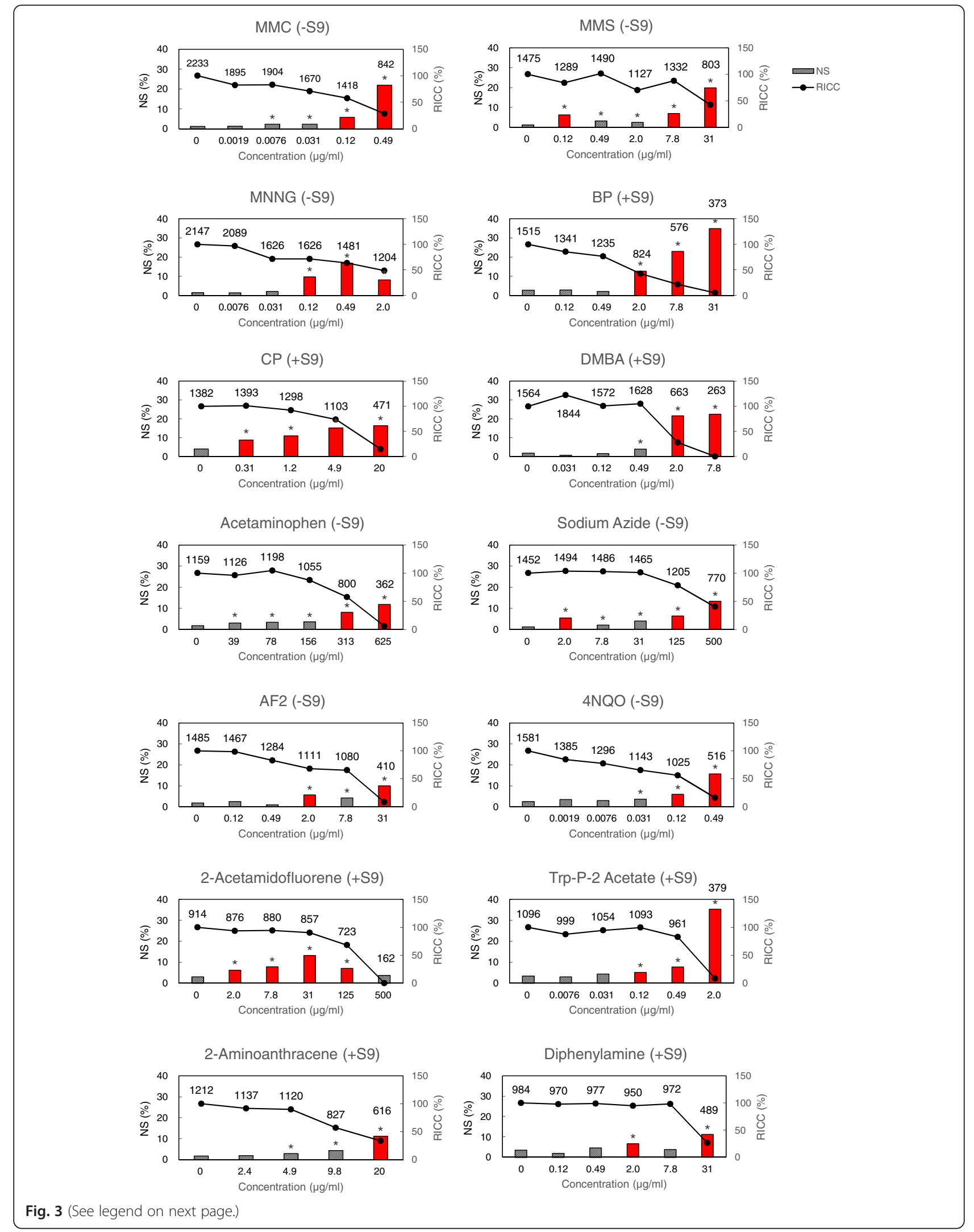


(See figure on previous page.)

Fig. 3 Clastogens induced nuclear swelling in L5178Y cells. NS = nuclear swelling (relative frequency of classes with swelling areas), RICC = relative increase in cell counts. $(-59)$ = without metabolic activation, (+S9) = with metabolic activation. The label values in the graph are the observed number of cells. Asterisks $\left(^{*}\right)$ indicate significant differences compared to controls $\left({ }^{*} p<0.05\right.$; Fisher's exact test or Chi-squared test). Nuclear swelling in the red bar graphs is $5 \%$ or more

\section{Discussion}

In the CHL cell tests using six types of clastogens, each compound showed a high correlation between CAs (\%) and NS (\%). Therefore, NS (\%), which does not depend on the abnormal enhancement of DNA synthesis, was due to the structural CAs in the interphase state. Normal individual chromosomes in interphase cell nuclei have a highly discrete compartment called chromosome territories [25].
Chromosomes damaged by radiation move into these chromosome territories [26]. Since clastogens also damage the structure of chromosomes, consequently, the chromosome territories might be distorted or destroyed. As a result, differences in the strain and stress of chromosome positioning will cause NS in interphase. Some of the differences between NS (\%) and CAs (\%) may be due to other factors contributing to NS. Since there are various

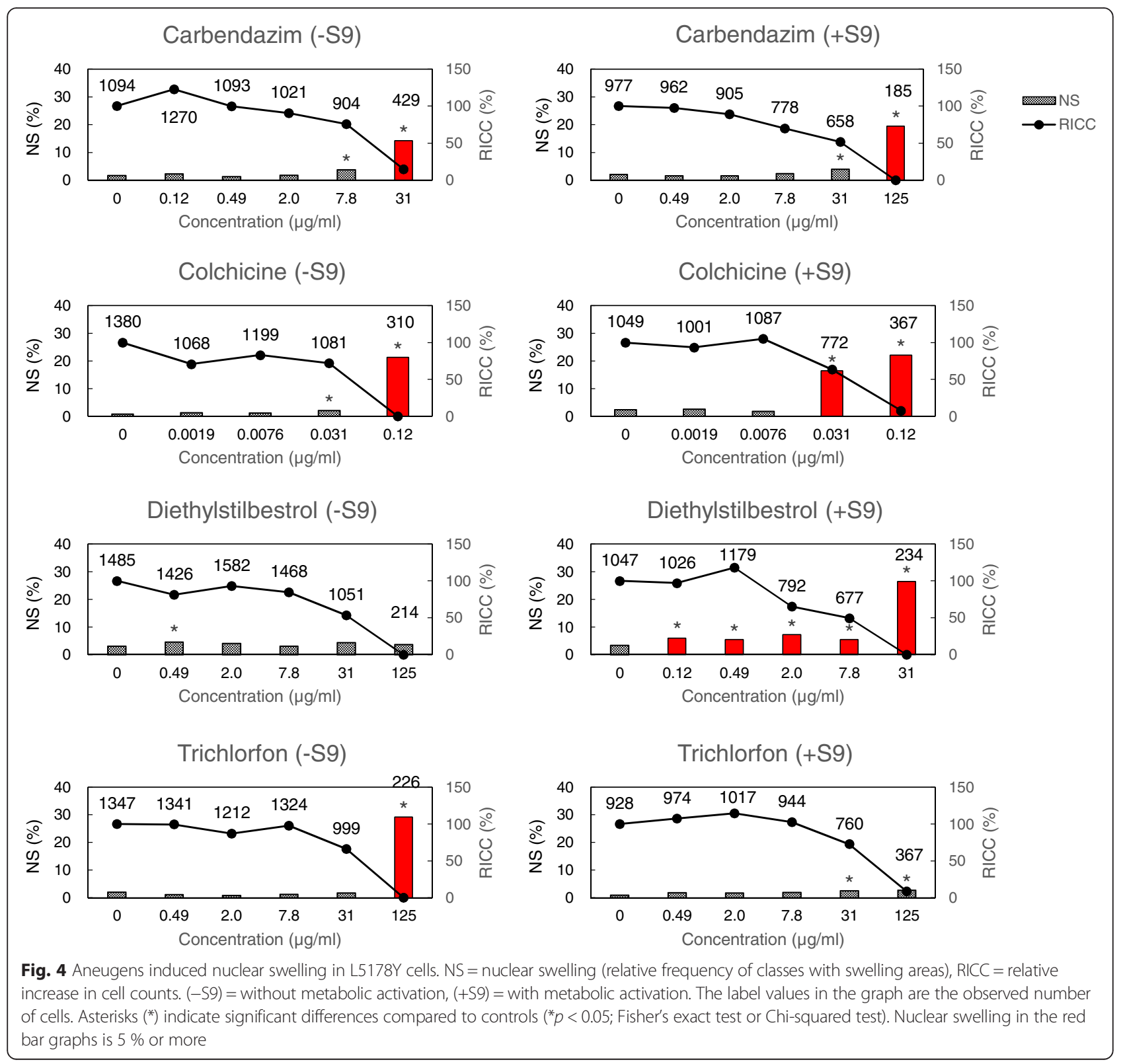




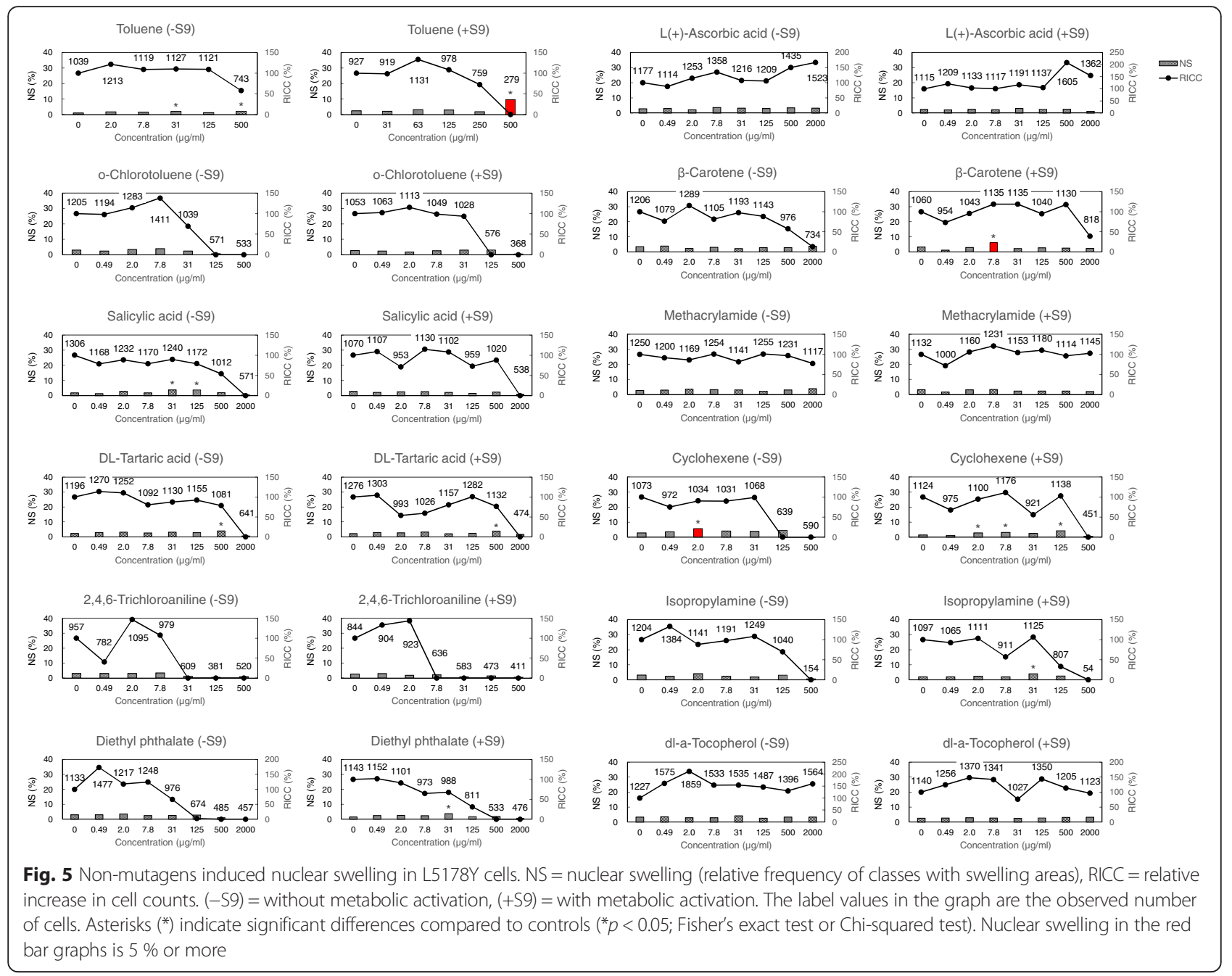

mechanisms for chromosome repair functions, the different characteristics of chemicals might affect the degree of NS (\%).

If NS reflects structural CAs, then a larger number of chromosomes in a cell may lead to a greater degree of
NS, provided that each chromosome has same basic volume irrespective of the cell nuclear species. For example, the number of chromosomes in CHL cells is 25 , while the number in L5178Y cells is 40, and thus the degree of NS in L5178Y cells is expected to be greater than that in

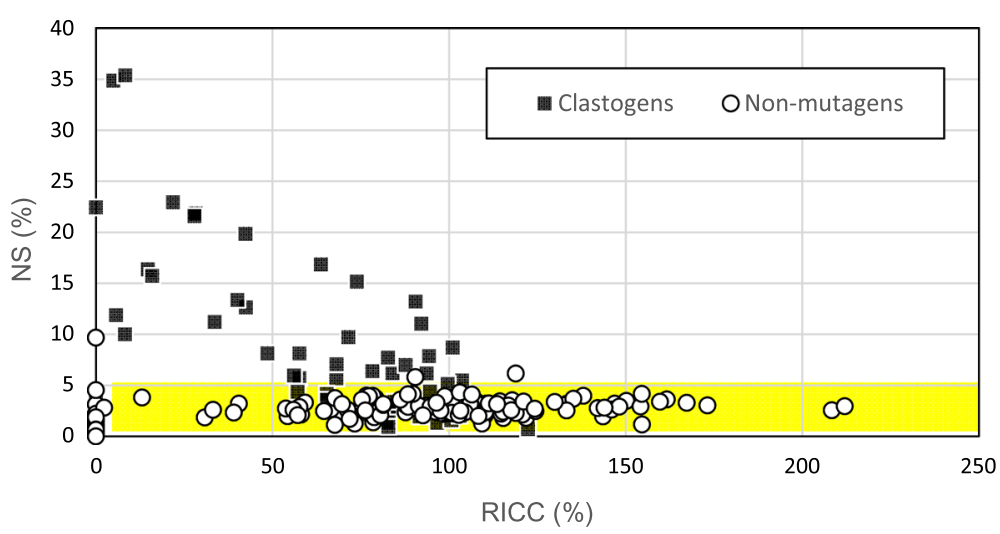

Fig. 6 Plots of nuclear swelling vs. RICC in L5178Y cells. NS = nuclear swelling, RICC = relative increase in cell counts 
CHL cells. However, the experimental results of swelling showed that both cells had similar cross-sections of approximately $30 \mu \mathrm{m}^{2}$, i.e., both cells showed nearly the same volumetric increase. These results do not support our hypothesis. However, the results suggest that a certain amount of space is required to repair structural chromosome aberrations in the nucleus.

In the L5178Y cell tests, the appearance of NS (\%) increased in a dose-dependent manner for almost clastogens tested. However, MNNG and 2-acetamidofluorene showed bell-shaped dose-response curves, and it was concluded that the cytotoxicity of these compounds was a more important factor than NS at high doses. In other words, the appearance of NS is due to factors other than cell death.

AF2 is a typical positive control. On the other hand, one study reported that diphenylamine caused micronuclei formation in human lymphocytes [27], and it is considered a weak clastogen [20]. These compounds caused similar degrees of NS (\%).

Colchicine causes NS, and it also causes structural and numerical CAs [28]. Thus, these characteristics are consistent with our experimental results in that colchicine caused higher NS (\%) values than the other aneugens. DES with metabolic activation caused NS (\%) at more than $5 \%$ relative frequency. There are reports that DES causes sister-chromatid exchanges and structural CAs in vitro in rodent cell lines $[29,30]$, and it is expected that DES will also cause NS. NS (\%) values following exposure to non-mutagens were greater than $5 \%$ at dosages of $500 \mu \mathrm{g} / \mathrm{ml}(+\mathrm{S} 9)$ for toluene, $7.8 \mu \mathrm{g} / \mathrm{ml}(+\mathrm{S} 9)$ for $\beta$-carotene, and $2.0 \mu \mathrm{g} / \mathrm{ml}(+\mathrm{S} 9)$ for cyclohexene. NS (\%) caused by toluene at high cytotoxicity levels is due to the same phenomenon that caused CAs at high cytotoxicity levels. The non-mutagens tested did not produce clearly defined NS (\%) in the present study. These results strongly suggest that NS associated with genotoxicity is caused by structural aberrations in the nucleus during interphase of the cell cycle.

NS during interphase (S, G2) is different from CAs that occur during the mitotic phase, as the cell has passed the G2/M checkpoint, but NS can be used to detect the effect of clastogens. The NS assay is a new method for assessing genotoxicity. This assay can also be applied in conjunction with other tests because it requires an extremely small amount of sample, and the assay can be automated to reduce the amount of time required.

\section{Conclusions}

In a short-term CA test using the fibroblast CHL cell line, the appearance of NS (\%) increased in a dose-dependent manner after exposure to six types of clastogens (MMC, MMS, MNNG, BP, CP, and DMBA), and a strong correlation was found between NS (\%) and CAs (\%) at each dosage. Therefore, we hypothesized that clastogens cause NS in cultured mammalian cells, since the mouse lymphoma L5178Y cell line is known to have a similar sensitivity to clastogens. Thus, we measured NS (\%) for 14 compounds (clastogens) that are known to induce structural CAs, 4 aneugens, and 12 non-mutagenes. Almost all clastogens caused NS (\%) of more than $5 \%$, which increased in a dose-dependent manner. Among the aneugens, colchicine, and diethylstilbestrol caused the same level of NS (\%) as the clastogens, while carbendazim and trichlorfon caused a similar level of NS (\%) as the clastogens only at higher levels of cytotoxicity. Almost all the non-mutagens caused less than $5 \%$ NS. These results strongly suggest that NS is mainly caused by structural aberrations in the nucleus during interphase of the cell cycle.

\section{Acknowledgements}

We would like to thank Dr. Tetsutaro Yoshinaga (former professor at Kyushu Kyoritsu University) and Dr. Masamitsu Honma (Chief, Division of Genetics \& Mutagenesis, National Institute of Health Sciences) for their scientific advice and encouragement. We would also like to thank UBE Scientific Analysis Laboratory, Inc. for the financial support.

\section{Authors' contributions}

KT made substantial contributions to the conception and design of the study, acquisition of the data, and analysis and interpretation of the data. HIO and TM were involved in drafting the manuscript and revising it critically for important intellectual content. TM has given final approval of the version to be published. All authors read and approved the final manuscript.

\section{Competing interests}

The authors declare that they have no competing interest.

Received: 13 November 2015 Accepted: 27 May 2016

Published online: 01 October 2016

\section{References}

1. Page RC. Cytologic changes in the skin of mice during application of carcinogenic agents. Arch Pathol. 1938;26:800-13.

2. Agrelo CE. The effect of carcinogens on the nuclear size of Hela cells. Toxicology. 1978;9:21-7.

3. Grant D, Grasso P. Suppression of Hela cell growth and increase in nuclear size by chemical carcinogens: a possible screening method. Mutation Res. 1978;57:369-80

4. Finch RA, Evans IM, Bosmann HB. Chemical carcinogen in vitro testing: a method for sizing cell nuclei in the nuclear enlargement assay. Toxicology. 1980;15:145-54.

5. Westmoreland C, Benford DJ, Eales LJ, Grasso P. Investigations into the mechanisms of carcinogen-induced nuclear enlargement in Hela S3 cells in vitro. Toxic In Vitro. 1994;8(5):1139-50.

6. Kobayashi Y, Sakemura R, Kumagai A, Sumikawa E, Fujii M, Ayusawa D. Nuclear swelling occurs during premature senescence mediated by MAP kinases in normal human fibroblasts. Biosci Biotechnol Biochem. 2008;72(4):1122-5

7. Johmura Y, Shimada M, Misaki T, Naiki-Ito A, Miyoshi H, Motoyama N, Ohtani N, Hara E, Nakamura M, Morita A, Takahashi S, Nakanishi M. Necessary and sufficient role for a mitosis skip in senescence induction. Mol Cell. 2014;55:1-12

8. Moore MM, Clive D, Hozier JC, Howard BE, Batson AG, Turner NT, Sawyer J. Analysis of trifluorothymidine-resistant (TFTr) mutants of L5178Y/TK+/- mouse lymphoma cells. Mutation Res. 1985;151:161-74.

9. Hozier J, Sawyer J, Clive D, Moor MM. Chromosome 11 aberrations in small colony L5178Y TK-/- mutants early in their clonal history. Mutation Res. 1985;147:237-42.

10. Doerr CL, Harrington-Brock K, Moore MM. Micronucleus, chromosome aberration, and small-colony TK mutant analysis to quantitate chromosomal damage in L5178Y mouse lymphoma cells. Mutation Res. 1989;222:191-203.

11. Honma M, Hayashi M, Shimada H, Tanaka N, Wakuri S, Awogi T, Yamamoto Kl, Kodani N, Nishi Y, Nakadate M, Sofuni T. Evaluation of the mouse lymphoma tk 
assay (microwell method) as an alternative to the in vitro chromosomal aberration test. Mutagenesis. 1999;14(1):5-22.

12. Lorge E, Thybaud V, Aardema MJ, Oliver J, Wakata A, Lorenzon G, Marzin D. SFTG international collaborative study on in vitro micronucleus test I. General conditions and overall conclusions of the study. Mutation Res. 2006;607:13-36.

13. ICH harmonised tripartite guideline, Guidance on Genotoxicity Testing and Data Interpretation for Pharmaceuticals Intended for Human Use S2(R1), Current Step 4 version dated 9 November 2011 (2.1 Rationale)

14. Ishidate Jr M. Data Book of Chromosomal Aberration Test in Vitro (in Japanese). Tokyo: L.I.C. Inc.; 1987.

15. Sofuni T, editor. Revised Edition 1998, Data Book of Chromosomal Aberration Test in Vitro (in Japanese). Tokyo: L.I.C. Inc.; 1999.

16. The MUTANTS: Database of Genotoxcity of Chemicals, http://members3. jcom.home.ne.jp/mo-ishidate/index.html. Accessed Nov 2015.

17. Ministry of Health, Labour and Welfare, Workplace safety site, mutagenicity test (Ames, chromosomal abnormality) Result http://anzeninfo.mhlw.go.jp/ user/anzen/kag/sokatutbl.htm. Accessed Nov 2015.

18. Mitchell AD, Auletta AE, Clive D, Kirby PE, Moore MM, Myhr BC. The L5178Y/ tk $+/$ - mouse lymphoma specific gene and chromosomal mutation assay a phase III report of the U.S. Environmental Protection Agency Gene-Tox Program. Mutation Res. 1997;394:177-303.

19. Pharmaceutical interview form-Terumo (This document include the clastogenicity of acetaminophen in L5178Y.), http://www.terumo.co.jp/ medical/drug/upload_files/acelio_if.pdf. Accessed Apr 2016

20. United States Environmental Protection Agency Pesticides: Reregistration, https://archive.epa.gov/pesticides/reregistration/web/html/status.html. Accessed Apr 2016.

21. United States National Library of Medicine, Toxicology Data Network (TOXNET), Chemical Carcinogenesis Research Information System (CCRIS), Genetic Toxicology Data Bank (GENE-TOX), http://toxnet.nlm.nih.gov/ newtoxnet/genetox.htm. Accessed Apr 2016.

22. OECD (2014), In Vitro Mammalian Cell Micronucleus Test, Test Guideline No. 487, OECD Guidelines for Testing of Chemicals

23. OECD (2014), In Vitro Mammalian Chromosomal Aberration Test, Test Guideline No. 473, OECD Guidelines for Testing of Chemicals

24. Galloway S, Lorge E, Aardema MJ, Eastmond D, Fellows M, Heflich R, Kirkland D, Levy DD, Lynch AM, Marzin D, Morita T, Schuler M, Speit G. Workshop summary: Top concentration for in vitro mammalian cell genotoxicity assays; and report from working group on toxicity measures and top concentration for in vitro cytogenetics assays (chromosome aberrations and micronucleus). Mutation Res. 2011;723:77-83.

25. Tanabe H. Chromosome territory: recent advancement of studies on interphase chromosome positioning in relation to nuclear architecture. Environ Mutagen Res. 2003;25:11-22.

26. Gandhi M, Evdokimova VN, Cuenco KT, Bakkenist CJ, Nikiforov YE. Homologous chromosomes move and rapidly initiate contact at the sites of double-strand breaks in genes in G-phase human cells. Cell Cycle. 2013;12(4):547-52.

27. Santovito A, Cervella P, Delpero M. Micronucleus frequency in human lymphocytes after exposure to diphenylamine in vitro. Mutation Res. 2012;747(1):135-7.

28. Arni P, Hertner T. Chromosomal aberrations in vitro induced by aneugens. Mutat Res. 1997;379:83-93.

29. Banduhn N, Obe G. Mutagenicity of methyl 2-benzimidazolecarbamate diethylstilbestrol and estradiol structural aberrations, sister-chromatid exchanges, C-mitosis, polyploidies and micronuclei. Mutation Res. 1985; 156(3):199-218.

30. Tayama S, Nakagawa Y, Tayama K. Genotoxic effects of environmental estrogen-like compounds in CHO-K1 cells. Mutat Res. 2008:649:114-25.

\section{Submit your next manuscript to BioMed Central and we will help you at every step:}

- We accept pre-submission inquiries

- Our selector tool helps you to find the most relevant journal

- We provide round the clock customer support

- Convenient online submission

- Thorough peer review

- Inclusion in PubMed and all major indexing services

- Maximum visibility for your research

Submit your manuscript at www.biomedcentral.com/submit
Biomed Central 